\title{
Penanda Molekuler Inter Simple Sequence Repeat untuk Menentukan Ketahanan Tanaman Jagung terhadap Penyakit Bulai
}

\author{
Inter Simple Sequence Repeat as Molecular Marker to Determine \\ Resistance to Downy Mildew in Maize
}

\author{
Polikarpia Wilhelmina Bani*, Budi Setiadi Daryono, Purnomo \\ Universitas Gadjah Mada, Yogyakarta 55281
}

\begin{abstract}
ABSTRAK
Penyakit bulai yang disebabkan oleh cendawan Peronosclerospora maydis dapat menurunkan hasil dan kualitas jagung secara nyata. Sifat ketahanan terhadap penyakit bulai pada tanaman jagung diperlukan untuk penetapan strategi pengendalian penyakit. Penanda molekuler biasanya digunakan untuk melihat variasi ketahanan tanaman terhadap penyakit. Penelitian ini menguji 5 primer inter simple sequence repeat (ISSR) sebagai penanda molekuler untuk menentukan ketahanan tanaman jagung terhadap penyakit bulai. Rata-rata polimorfik 5 primer ISSR yang digunakan ialah $72.84 \%$. Primer ISSR 808 (AG) 8C mampu membedakan jagung kultivar Talenta yang tahan bulai dari kultivar Pulut yang rentan.

Kata kunci: kultivar tahan, Peronosclerospora maydis, polimorfik, primer
\end{abstract}

\begin{abstract}
Downy mildew disease of maize, caused by the fungus Peronosclerospora maydis, can cause serious yield loss. Molecular markers-based method is usually performed to look for the variation of resistance in plants. In this study, 5 primers of inter simple sequence repeat (ISSR) was evaluated for molecular marker to determine maize resistance to downy mildew. The average polymorphic of 5 ISSR primers was $72.84 \%$. Primer ISSR 808 (AG) $8 \mathrm{C}$ was able to differentiate resistant cultivar (cv Talenta) from susceptible cultivar (cv Pulut).
\end{abstract}

Key words: Peronosclerospora maydis, polymorphic, primer, resistant cultivar

*Alamat penulis korespondensi: Laboratorium Genetika, Fakultas Biologi Universitas Gadjah Mada. Jalan Teknika Selatan, Sekip Utara, Yogyakarta, 55281

Tel: 0274-580839;0274-6492354;0274-6492355; Surel:helmi_bani@yahoo.com 


\section{PENDAHULUAN}

Jagung (Zea mays) merupakan tanaman pangan penting bagi Indonesia dan dunia. Salah satu kendala biotik yang mengganggu ialah penyakit bulai yang disebabkan cendawan dari genus Peronosclerospora, Sclerospora, dan Scleropthora. Tiga spesies cendawan semu dari genus Peronosclerospora yang menyebabkan penyakit bulai cukup berbahaya karena dapat menyebabkan kehilangan hasil panen hingga 100\% (Rustiani 2015).

Keanekaragaman genetika dalam varietas jagung di Indonesia berpotensi menjadi sumber karakter unggulan guna mengatasi berbagai kendala dalam budi daya jagung di Indonesia. Informasi hubungan kekerabatan di antara materi pemuliaan berperan penting dalam pemilihan tetua secara efisien melalui program pemuliaan tanaman (Pabendon et al 2007). Analisis variasi genetika dapat dilakukan melalui identifikasi karakter morfologi dan molekuler. Identifikasi karakter morfologi tanaman ialah identifikasi terhadap karakter luar tanaman baik kualitatif maupun kuantitatif. Identifikasi karakter morfologi memiliki kelemahan, yaitu penampilan sering dipengaruhi oleh faktor lingkungan. Oleh karena itu, identifikasi karakter molekuler dibutuhkan untuk melengkapi informasi morfologi dalam menentukan tetua yang digunakan dalam pemuliaan tanaman dan perakitan varietas (Valdemar et al. 2002).

Penanda molekuler inter simple sequence repeat (ISSR) merupakan penanda molekuler yang umumunya digunakan untuk studi keanekaragaman genetika, filogeni, penandaan gen, pemetaan genom dan biologi evolusi pada berbagai tanaman (Reddy et al. 2002). Penanda molekuler ISSR menggunakan primer tunggal untuk menargetkan daerah identik antara mikrosatelit, yaitu daerah pengulangan simple sequence repeat (SSR). Primer ISSR terdiri atas 8 unit dinukleotida berulang (atau 6 unit trinukleotida berulang) dan satu atau lebih jangkar nukleotida yang dirancang untuk menargetkan akhir wilayah mikrosatelit dan mencegah dimerisasi primer. Urutan berulang pada SSR yang tidak dipisahkan oleh ISSR akan cenderung mengalami self annealed. Primer ISSR menghasilkan polimorfisme setiap kali salah satu genom kehilangan urutan berulang atau ketika terjadi delesi, insersi atau translokasi yang mengubah jarak antara urutan berulang. Biasanya dinukleotida jangkar mengait pada ujung 3' atau 5' menunjukkan polimorfisme tinggi (Blair et al. 1999). Oleh karena itu, digunakan penanda molekuler ISSR untuk mengamati variasi genetika pada jagung berdasarkan karakter molekuler dan mendeteksi gen ketahanan terhadap penyakit bulai pada jagung.

Penelitian mengenai variasi genetika pada jagung menggunakan karakter molekuler dengan penanda ISSR sudah dilakukan oleh Valdemar et al. (2002), Idris et al. (2012), dan Antonio et al. (2011). Hasil-hasil penelitian tersebut digunakan sebagai acuan untuk studi variasi genetika pada jagung dengan aplikasi penanda ISSR.

\section{BAHAN DAN METODE}

Bahan yang digunakan dalam penelitian ini ialah 12 kultivar jagung yaitu 'Gama GS' (Fakultas Biologi UGM), 'Gama SG' (Fakultas Biologi UGM), 'Bisi-816' (PT. BISI International, Tbk.), 'Pioneer-21' (Thailand), 'Lagaligo' (Balitseral Maros), 'Talenta' (PT. Agri Makmur Pertiwi), 'Pulut' (Balitseral Maros), 'Pena Molo' (NTT), 'Pena Fatu' (NTT), 'Pena Kikis' (NTT), 'Pena Moi' (NTT), dan 'Pena Boto' (Masyarakat/petani lokalNTT).

\section{Karakterisasi Fenotipe}

Penanaman dan pengamatan karakter fenotipe dilakukan di Pusat Inovasi dan Agro Teknologi (PIAT) UGM Desa Kalitirto, Sleman, DIY. Pengukuran karakter fenotipe dilakukan saat jagung berumur100 hari setelah tanam (HST) ketika tanaman jagung mencapai masak fisiologis. Persentase ketahanan jagung terhadap infeksi penyakit bulai di lapangan dilakukan dengan menghitung insidensi penyakit (IP) menggunakan rumus:

$$
\mathrm{IP}=\frac{\mathrm{n}}{\mathrm{N}} \times 100 \% \text {, dengan }
$$


$\mathrm{n}$, jumlah tanaman yang terserang dan $\mathrm{N}$, jumlah tanaman yang diamati.

Karakter fenotipe yang diamati berjumlah 15 karakter terdiri atas 2 karakter habitus tanaman (tinggi tanaman dan tinggi letak tongkol), 1 karakter batang (diameter batang), 3 karakter daun (panjang daun, lebar daun dan jumlah daun), 1 karakter malai (jumlah malai), 1 karakter waktu berbunga (umur berbunga), 6 karakter tongkol (panjang tongkol, diameter tongkol, bobot tongkol, jumlah biji per baris, jumlah baris biji per tongkol, dan bobot 100 biji per tongkol), dan 1 karakter ketahanan fenotipeik terhadap infeksi penyakit bulai di lapangan. Ketahanan jagung terhadap penyakit bulai dihitung berdasarkan persentase jagung yang terinfeksi penyakit bulai di lapangan (Rais et al. 2002). Respons ketahanan jagung dapat dibedakan atas kategori sangat rentan $(>60 \%)$, rentan (41-60\%), agak tahan (21-40\%), tahan (11-20\%), dan sangat tahan $(0-10 \%)$. Analisis hubungan kekerabatan karakter fenotipe menggunakan program multi variate statistical package (MVSP).

\section{Isolasi DNA}

Prosedur isolasi DNA mengikuti metode Kit Nucleon Phytopure (GE Healthcare, UK) dengan modifikasi pada bobot daun, volume pereaksi, jumlah kloroform, dan jumlah resin. Daun tanaman jagung dipotong dan sebanyak $0.3 \mathrm{~g}$ diberi nitrogen cair kemudian digerus menggunakan pistil. Sampel dimasukkan ke dalam tabung $1.5 \mu \mathrm{L}$ dan ditambahi $400 \mu \mathrm{L}$ pereaksi "phytopure I". Selanjutnya, $100 \mu \mathrm{L}$ pereaksi "phytopure II" ditambahkan dan diinkubasi pada suhu $65^{\circ} \mathrm{C}$ selama 10 menit di penangas air. Setelah diinkubasi, sampel diletakkan dalam lemari es selama 20 menit, kemudian dimasukkan $400 \mu \mathrm{L}$ kloroform dingin dan ditambahkan $50 \mu \mathrm{L}$ resin phytopure. Sampel yang sudah diberi resin phytopure disentrifugasi dengan kecepatan $3000 \times \mathrm{g}$ selama 10 menit. Supernatan dipindahkan ke tabung baru ukuran $1.5 \mathrm{~mL}$, ditambahi isopropanol atau propanol dingin dengan volume yang sama dengan volume supernatan, kemudian disentrifugasi pada kecepatan $1000 \times$ g selama 10 menit. Pelet DNA yang diperoleh dicuci dengan cara menambahkan $100 \mu \mathrm{L}$ etanol $70 \%$ dan selanjutnya disentrifugasi dengan kecepatan $10000 \times \mathrm{g}$ selama 5 menit. Pelet DNA kering selanjutnya ditambahi $50 \mathrm{~mL}$ bufer $1 \times$ TE.

\section{Analisis ISSR-PCR}

Campuran PCR terdiri atas $10.5 \mu \mathrm{L}$ aquabides, $12.5 \mu \mathrm{L}$ mastermix Dream Taq ${ }^{\mathrm{TM}}$ Green (Thermo Fisher Scientific), $1 \mu \mathrm{L}$ primer (sikuen-807, sikuen-810, sikuen-814, sikuen-841, dan sikuen-808), dan $1 \mu \mathrm{L}$ templat DNA dari $1 / 75$ konsentrasi isolat DNA. Pelaksanaan amplifikasi dilakukan pada suhu denaturasi $94{ }^{\circ} \mathrm{C}$ selama 2 menit, aneling bervariasi bergantung pada jenis primer (45$51^{\circ} \mathrm{C}$ ) sintesis $72^{\circ} \mathrm{C}$ selama 1 menit, siklus diulang sebanyak $40 \mathrm{kali}$; dan perpanjangan basa-basa nukleotida pada suhu $72{ }^{\circ} \mathrm{C}$ selama 5 menit (Idris et al. 2012). Produk amplifikasi dipisahkan dengan elektroforesis pada gel agarosa $2 \%$ pada tegangan 100 volt selama 30-45 menit. Visualisasi pita DNA dilakukan menggunakan transiluminator sinar UV.

\section{Analisis Data}

Data fenotipe agronomi yang diperoleh dianalisis dengan program Microsoft Excel untuk mengetahui nilai rata-rata setiap parameter karakter fenotipe. Data matriks kemiripan dibuat dalam bentuk dendogram menggunakan metode unweightedpair-group methode using arithmeticaverage (UPGMA). Kemudian, data dianalisis principal component analysis (PCA) untuk mendapatkan data pengelompokan dari 12 kultivar jagung.

Data molekuler berdasarkan penanda ISSR didasarkan pada kemunculan pita DNA. Profil pita DNA diterjemahkan ke dalam data biner dengan ketentuan nilai 0 bila pita DNA tidak muncul dan nilai 1 bila terdapat pita DNA pada suatu posisi yang sama dari individu yang dibandingkan. Pengelompokan data matrik (cluster analysis) dan pembuatan dendogram menggunakan metode UPGMA. 


\section{HASIL}

Analisis pengelompokan yang diturunkan dari matriks kemiripan fenotipe tanaman jagung menghasilkan 2 kelompok. Kelompok A terdiri atas kultivar Pulut, sedangkan kelompok B terdiri atas 11 kultivar lainnya. Lebih lanjut, kelompok B terbagi lagi menjadi 3 subkelompok, yaitu subkelompok 2, 3, dan 4. Kultivar Pulut memisah dari kelompok B (subkelompok 2, 3, dan 4) dan membentuk subkelompok 1 karena perbedaan mendasar pada ketahanan fenotipe terhadap penyakit bulai. Kultivar Pulut memberikan respons sangat rentan atau $100 \%$ terinfeksi penyakit bulai. Kultivar 'Pena Moi', 'Pena Kikis', 'Pena Boto' dan 'Pena Fatu' membentuk subkelompok 2 karena persamaan 9 karakter fenotipe, yaitu tinggi tanaman, tinggi letak tongkol, jumlah daun, panjang daun, lebar daun, diameter batang, jumlah percabangan malai, bobot tongkol, dan jumlah biji per baris. 'Pena Molo' terpisah dan membentuk subkelompok 3 karena dari 15 karakter fenotipe tidak memiliki kesamaan dengan 3 kelompok lainnya. Kultivar 'Bisi-816', 'Pioneer-21', 'Gama GS', 'Gama SG', 'Lagaligo', dan 'Talenta' berada pada subkelompok 4 dengan tingkat kemiripan $0.78 \%$ untuk 10 karakter fenotipe, yaitu tinggi tanaman, tinggi letak tongkol, jumlah daun, panjang daun, lebar daun, diameter batang, waktu berbunga, jumlah percabangan malai, panjang tongkol, dan jumlah biji per baris. Pengelompokan kultivar pada subkelompok 1 dan 2 didominasi oleh kultivar yang rentan terhadap penyakit bulai di lapangan dan kultivar jagung lokal Pulau Timor; sedangkan subkelompok 3 dan 4 didominasi oleh kultivar yang tahan dan sangat tahan terhadap penyakit bulai di lapangan dan kultivar yang diterbitkan oleh Kementerian Pertanian (Gambar 1).

Seluruh data fenotipe digunakan dalam analisis lanjutan menggunakan program PCA dengan tujuan mengetahui variabel atau karakter fenotipe yang paling berperan dalam pengelompokan kultivar untuk mendapatkan 5 kelompok (A, B, C, D, dan E) (Gambar 2). Pada kelompok A terdapat kultivar 'Pena Fatu', 'Pena Boto', 'Pena Kikis', dan 'Pena Moi'; pada kelompok B terdapat kultivar 'Gama SG', 'Gama GS', dan 'Pena Molo'; dan pada kelompok $\mathrm{C}$ terdapat kultivar 'Talenta', 'Bisi-816', dan 'Lagaligo'. Kultivar 'P-21' pada axis 2 (kelompok D) dan 'Pulut' pada axis 1 (kelompok E) terpisah, masing-masing membentuk kelompok sendiri. Kedua kultivar ini berada di luar kelompok A, B, dan C yang artinya memiliki tingkat kesamaan yang rendah dengan anggota kelompoknya. Hasil analisis PCA juga menunjukkan bahwa variabel atau karakter fenotipe yang paling berperan dalam pengelompokan kultivar ialah waktu berbunga, diameter batang dan jumlah biji per baris.

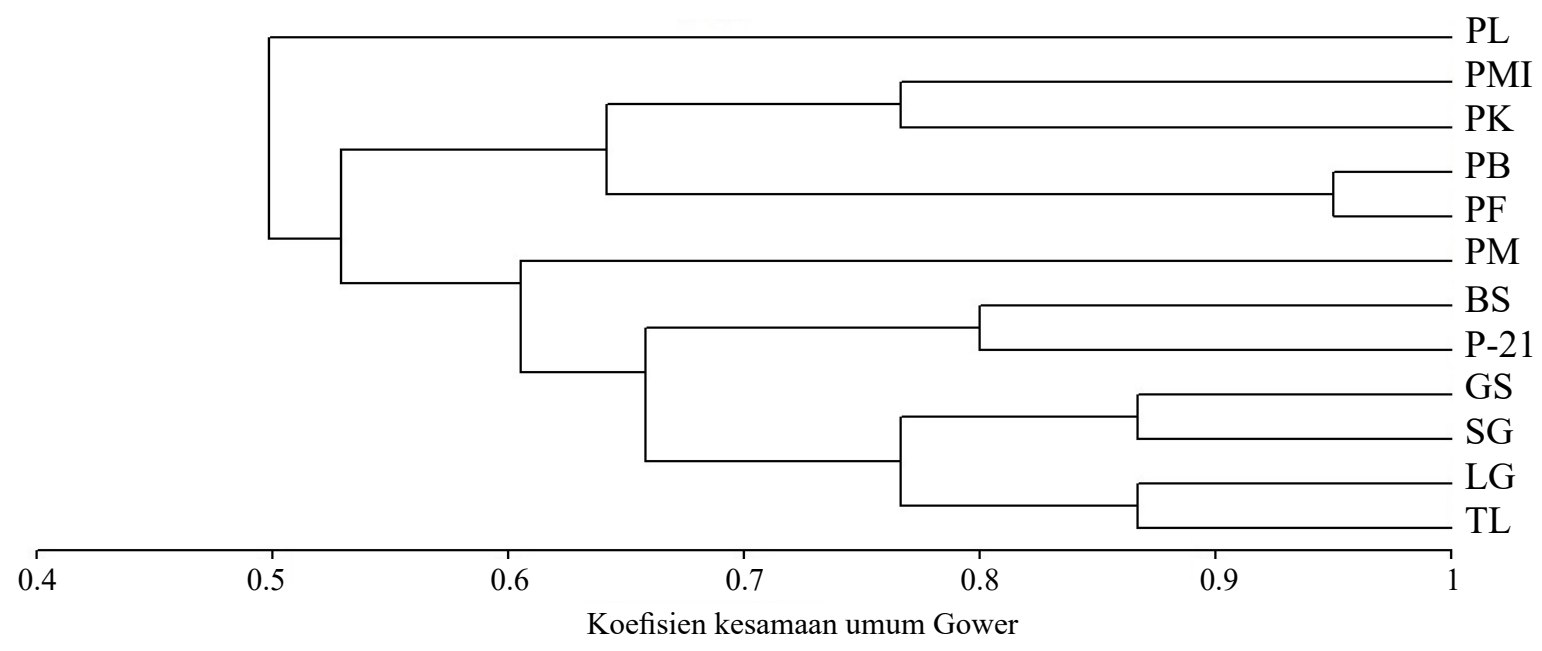

Gambar 1 Filogenetika berdasarkan karakter fenotipe 12 kultivar jagung. TL, 'Talenta'; P-21, 'Pioneer-21'; SG, 'Gama SG'; GS, 'Gama GS'; BS, 'Bisi-816'; LG, 'Lagaligo'; PL, 'Pulut'; PM, 'Pena Molo'; PF, 'Pena Fatu’; PB, 'Pena Boto'; PK, 'Pena Kikis’; PMI, 'Pena Moi’. 
Pengelompokan kultivar membentuk 2 kelompok besar (A dan B) pada kemiripan $0.78 \%$ dan terdapat pembagian sebanyak 5 subkelompok. Kelompok A terbagi lagi menjadi subkelompok 1 dan 2; sedangkan kelompok B terbagi menjadi subkelompok 3, 4, dan 5. Tidak terdapat pengelompokan antar kultivar yang menunjukkan perbedaan antara kultivar yang tahan dan rentan penyakit bulai. Antara kultivar yang tahan dan kultivar yang rentan tidak memisah atau tetap menyatu membentuk satu subkelompok yang sama. Namun, penanda molekuler ISSR menghasilkan pengelompokan kultivar berdasarkan pada daerah asal jagung, yakni kultivar jagung lokal Pulau Timor pada kelompok A dan kultivar yang diterbitkan oleh Kementerian Pertanian pada kelompok B (Gambar 3). Ketahanan 12 kultivar sangat bervariasi, yaitu terdapat kultivar yang sangat tahan, tahan, agak tahan, rentan, dan sangat rentan (Tabel 1).

Analisis ISSR dengan amplifikasi menggunakan 5 primer menghasilkan 404 pita DNA yang terdiri atas 58 pita DNA polimorfik (72.84\%) dan 1 pita DNA monomorfik (Tabel2). Lokus pita DNA polimorfik terdapat berkisar antara 8 untuk $(\mathrm{CT})_{8}$ A sampai 15 untuk $(\mathrm{AG})_{8} \mathrm{~T}$.

Berdasarkan pengamatan respons varietas, kultivar 'Bisi-816' tergolong tahan dengan nilai
IP sebesar 20\%. Kultivar dengan respons rentan ialah 'Pena Boto', 'Pioneer-21', 'Pena Moi', dan 'Pena Kikis' dengan IP berturut-turut $48.31 \%$, $48.71 \%$, 51\%, dan 56\%. Kultivar dengan respons agak tahan ialah 'Pena Fatu' dengan IP sebesar 25.71\%; sedangkan kultivar dengan respons sangat rentan ialah 'Pulut', 'Gama SG', dan 'Gama GS' dengan IP berturut-turut 100\%, $89 \%, 87.80 \%$. Hasil penelitian ini sejalan dengan yang dikemukakan oleh Kementerian Pertanian RI maka kultivar 'Talenta', 'Bisi-816' dan 'Lagaligo' terbukti sangat tahan terhadap penyakit bulai di lapangan. Begitu pula dengan kultivar 'Pioneer-21' dan 'Pulut' terbukti rentan terhadap penyakit bulai di lapangan. Kultivar 'Gama GS' dan, 'Gama SG', ke-5 jagung lokal Pulau Timor yaitu 'Pena Molo', 'Pena Fatu', 'Pena Boto', 'Pena Kikis', dan 'Pena Moi' belum didaftarkan di Kementrian Pertanian (Kementan) sehingga penelitian ini memberikan informasi baru mengenai status ketahanannya terhadap penyakit bulai di lapangan.

\section{PEMBAHASAN}

Semakin tinggi nilai indeks kesamaan maka hubungan kekerabatan di antara sampel yang diuji semakin dekat. Apabila indeks kesamaan $>70 \%$ ini menggambarkan bahwa varietas yang

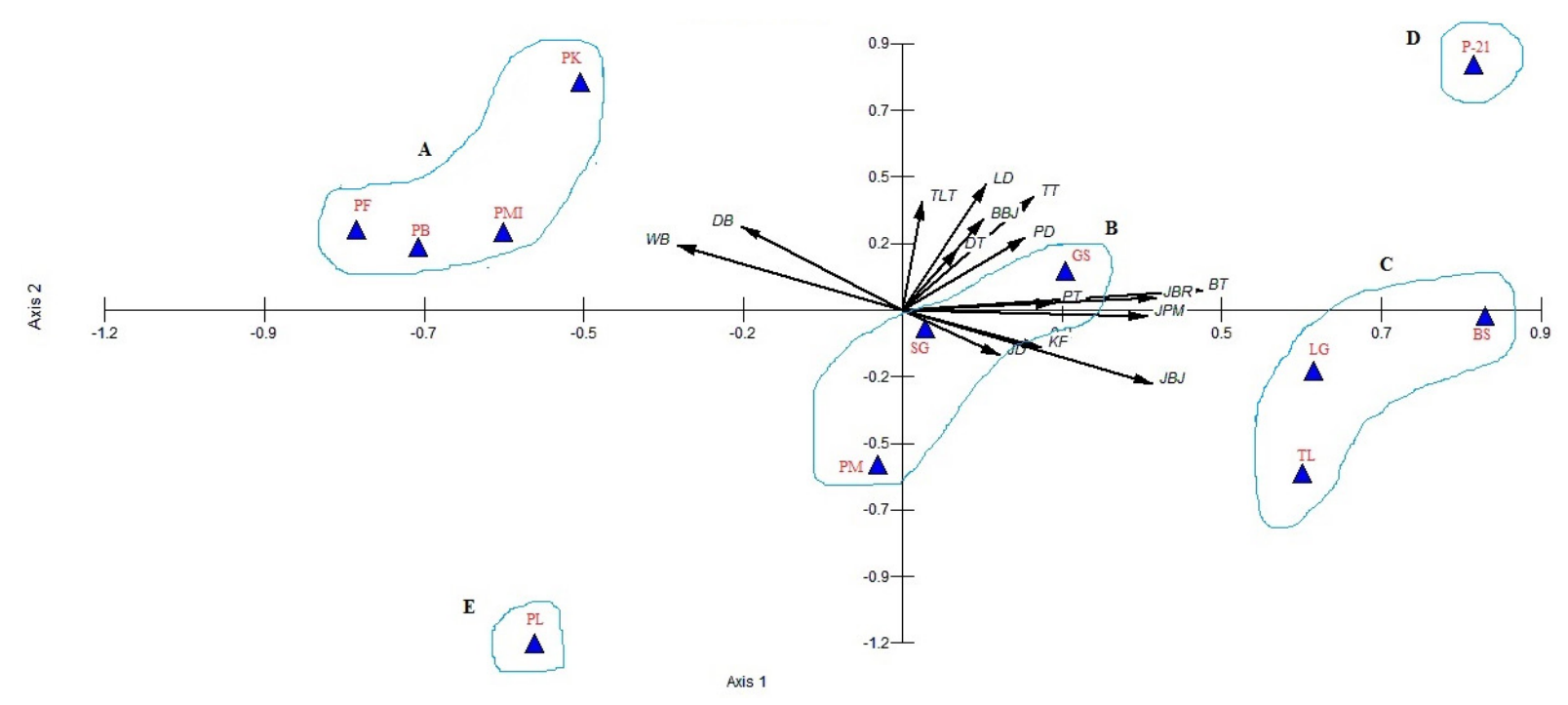

Gambar 2 Plot principal component analysis (PCA) 12 kultivar jagung. TL, 'Talenta'; P-21, 'Pioneer-21'; SG, 'Gama SG'; GS, 'Gama GS'; BS, 'Bisi-816';LG, 'Lagaligo'; PL, 'Pulut'; PM, 'Pena Molo'; PF, 'Pena Fatu'; PB, 'Pena Boto'; PK, 'Pena Kikis'; PMI, 'Pena Moi’. 


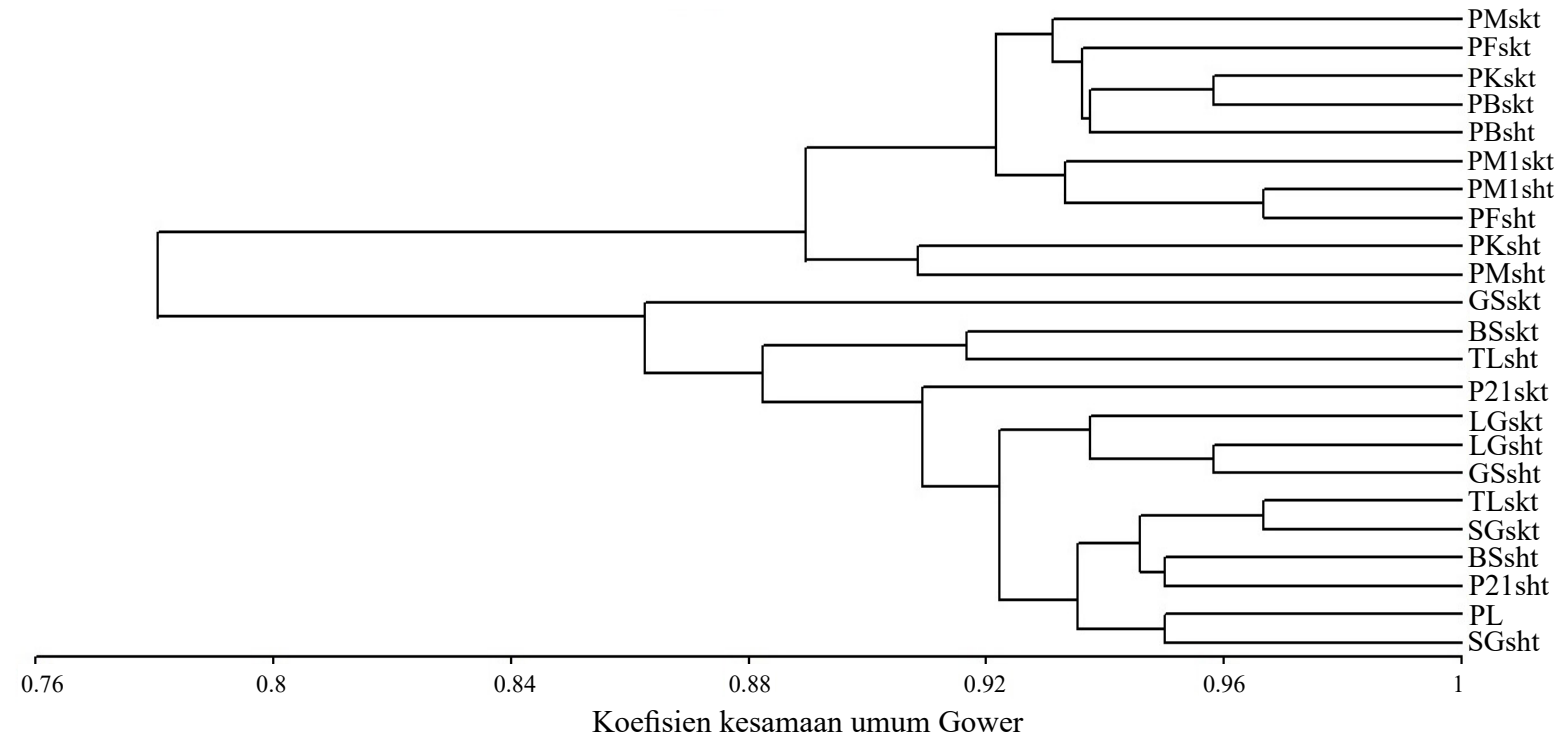

Gambar 3 Pohon Filogenetika 12 kultivar jagung berdasarkan penanda ISSR. TL, 'Talenta'; P-21, 'Pioneer-21'; SG, 'Gama SG'; GS, 'Gama GS'; BS, 'Bisi-816';LG, 'Lagaligo'; PL, 'Pulut'; PM, 'Pena Molo'; PF, 'Pena Fatu'; PB, 'Pena Boto'; PK, 'Pena Kikis'; PMI, 'Pena Moi'. sht, tanaman sehat; skt, tanaman sakit.

Tabel 1 Persentase ketahanan jagung yang terinfeksi penyakit bulai di lapangan

\begin{tabular}{lccccc}
\hline Kultivar & $\sum$ total & $\sum$ yang & Insidensi & \multicolumn{2}{c}{ Respons tanaman } \\
\cline { 5 - 6 } jagung & individu & terinfeksi & penyakit (\%) & Penelitian & Kementerian Pertanian* \\
\hline Talenta & 164 & 2 & 1.00 & Sangat tahan & Tahan \\
Pioneer-21 & 164 & 80 & 48.78 & Rentan & Agak rentan \\
Gama GS & 164 & 144 & 87.80 & Sangat rentan & - \\
Gama SG & 164 & 146 & 89.00 & Sangat rentan & - \\
Bisi-816 & 164 & 34 & 20.00 & Tahan & Tahan \\
Lagaligo & 164 & 17 & 10.00 & Sangat tahan & Tahan \\
Pulut & 80 & 80 & 100.00 & Sangat rentan & Agak tahan \\
Pena Molo & 111 & 4 & 3.60 & Sangat tahan & - \\
Pena Fatu & 70 & 18 & 25.71 & Agak tahan & - \\
Pena Boto & 89 & 43 & 48.31 & Rentan & - \\
Pena Kikis & 82 & 46 & 56.00 & Rentan & - \\
Pena Moi & 66 & 34 & 51.00 & Rentan & - \\
\hline
\end{tabular}

*Balai Penelitian Bioteknologi dan Sumberdaya Genetik Pertanian (Rais et al. 2002).

Tabel 2 Polimorfisme pita DNA hasil amplifikasi ISSR

\begin{tabular}{lccccc}
\hline Primer & $\begin{array}{c}\text { Jumlah } \\
\text { pita DNA }\end{array}$ & $\begin{array}{c}\text { Total } \\
\text { lokus }\end{array}$ & $\begin{array}{c}\text { Jumlah lokus } \\
\text { polimorfik }\end{array}$ & $\begin{array}{c}\text { Jumlah lokus } \\
\text { monomorfik }\end{array}$ & $\begin{array}{c}\text { Polimorfisme } \\
(\%)\end{array}$ \\
\hline 807 & 95.0 & 15.0 & 15.0 & - & 15.78 \\
810 & 69.0 & 13.0 & 13.0 & - & 18.84 \\
814 & 61.0 & 8.0 & 8.0 & - & 13.11 \\
841 & 97.0 & 12.0 & 11.0 & 1.0 & 11.34 \\
808 & 82.0 & 11.0 & 11.0 & - & 13.41 \\
\hline Total & 404.0 & 59.0 & 58.0 & 1.0 & 72.48 \\
Rata-rata & 80.8 & 11.8 & 11.6 & 0.2 & 14.49 \\
\hline
\end{tabular}


dibandingkan memiliki kesamaan yang dekat sehingga variasi genetika semakin rendah. Hal ini disebabkan oleh tingginya persamaan dan kemiripan karakter pada varietas tersebut, karena semakin tinggi persamaan karakter antarvarietas, maka semakin rendah tingkat keragamannya (Mustofa et al. 2013).

Penghanyutan genetika (gene flow) dan seleksi pada lingkungan yang berbeda dapat menyebabkan diversitas genetika yang lebih besar dibandingkan dengan jarak wilayah tempat tumbuh tanaman. Pernyataan tersebut menjelaskan bahwa meskipun suatu genotipe jagung berasal dari tempat yang sama, namun bila lingkungan tempat tumbuhnya berbeda akan memengaruhi diversitas genetika. Semakin banyak persamaan karakter fenotipe yang dimiliki menunjukkan bahwa semakin dekat hubungan kekerabatan, sebaliknya semakin sedikit persamaan karakter yang dimiliki semakin jauh hubungan kekerabatannya (Sokal dan Sneath 1963).

Tingkat polimorfisme pada penelitian ini tidak jauh berbeda dengan hasil penelitian Valdemar et al. (2002) pada studi diversitas genetika jagung menggunakan ISSR. Selain itu, hasil penelitian ini mendekati hasil penelitian Idris et al. (2012) dan Antonio et al. (2011) yang menggunakan penanda molekuler ISSR untuk analisis variasi genetika pada jagung dengan persentase polimorfik berturut-turut $85.4 \%$ dan $89.05 \%$.

Variasi fenotipe plasma nutfah jagung dapat dipengaruhi oleh lingkungan seperti jenis tanah, $\mathrm{pH}$, ketinggian dan kelembapan. Faktor lingkungan cenderung memengaruhi karakter kuantitif seperti tinggi tanaman, diameter batang, ukuran daun, dan ketahanan terhadap penyakit bulai. Tingkat ketahanan jagung terhadap patogen penyebab penyakit bulai cukup beragam, bergantung pada variabilitas genetik, variabilitas fenotipik, dan interaksi antara genetika dengan lingkungannya. Kultivar yang sangat tahan, tahan maupun agak tahan mampu menghambat perkembangan patogen sehingga patogen tersebut tidak dapat berkembang dan menyebar; sebaliknya yang terjadi pada tumbuhan rentan dan sangat rentan. Respons tanaman terhadap patogen dipengaruhi oleh faktor genetika dan lingkungan (Azrai et al. 2006). Ketahanan 12 kultivar jagung dalam penelitian ini sesuai dengan lokasi budi daya, yaitu di lokasi terbuka dengan suhu dan kelembapan yang mendukung untuk pertumbuhan Peronosclerospora pada malam hari. Pertumbuhan $P$. maydis di bawah suhu $24{ }^{\circ} \mathrm{C}$ sesuai dengan keadaan pada lokasi budi daya dan penularannya dari tanaman sakit ke tanaman sehat terjadi melalui angin pada pagi hari.

Analisis hubungan kekerabatan dengan program multi variate statistical package (MVSP) berdasarkan karakter fenotipe menunjukkan nilai indeks kemiripan yang rendah artinya variasi karakter fenotipe sangat tinggi. Hal ini menunjukkan bahwa faktor lingkungan sangat berpengaruh terhadap perubahan fenotipe suatu kultivar jagung. Berdasarkan hasil penelitian ini, penanda molekuler ISSR menghasilkan pengelompokan kultivar berdasarkan pada daerah asal jagung, yaitu kultivar jagung lokal Pulau Timor pada kelompok A dan kultivar yang diterbitkan Kementerian Pertanian pada kelompok B. Selain pengelompokan tersebut, resistensi tanaman terhadap patogen dikendalikan oleh gen tanaman tersebut. Interaksi gen tahan berpengaruh pula terhadap perkembangan suatu penyakit, di mana pada varietas tahan perkembangannya akan lebih lambat dibanding dengan varietas yang rentan. Secara genetika sifat ketahanan varietas tahan biasanya dipengaruhi oleh adanya sejumlah gen yang menyusun kromosom, di mana tanaman disusun oleh beberapa gen tahan yang dikenal dengan ketahanan horizontal. Gen tahan mengendalikan metabolisme produksi toksin yang dihasilkan oleh tanaman yang dapat menekan perkembangan penyakit (Muis et al. 2015).

Penelitian terdahulu tentang ketahanan tanaman jagung terhadap penyakit bulai dilaporkan ada tanaman yang tahan, agak tahan, rentan, dan sangat rentan. Hasil penelitian ini mengindikasikan tanaman jagung lokal lebih tahan terhadap penyakit bulai dibandingkan dengan varietas impor (Hartatik 2007). Pengamatan karakter fenotipe jagung lokal 
NTT memperkuat hasil penelitian sebelumnya bahwa jagung lokal tahan terhadap penyakit bulai.

Identifikasi lokus karakter kuantatif ketahanan penyakit bulai pada jagung menggunakan penanda molekuler RFLP sudah dilaporkan (Azrai 2003). Hasil yang diperoleh menunjukkan bahwa ada 2 penanda yang berasosiasi sangat kuat dengan gen ketahanan penyakit bulai, yaitu interval penanda bnl18.23bnl5.47a, dan bnl5.47a. Pemanfaatan penanda molekuler dapat mempercepat proses seleksi dan hasilnya lebih menyakinkan dibandingkan dengan pemuliaan secara konvensional.

Penggunaan penanda molekuler ISSR untuk menentukan ketahanan jagung terhadap penyakit bulai pada varietas jagung yang diterbitkan oleh Kementerian Pertanian RI dan jagung lokal NTT diperoleh pita spesifik pada primer ISSR 808 teramplifikasi pada ukuran $300 \mathrm{pb}$ pada kultivar 'Talenta'. Disimpulkan bahwa penanda molekuler ISSR dapat menentukan adanya ketahanan pada vairetas jagung terhadap penyakit bulai. Sifat ketahanan tanaman sering dikendalikan oleh gen-gen inti dan atau gen-gen sitoplasma sehingga penggunaan penanda molekuler sangat penting untuk mendeteksi gen ketahanan. Akan tetapi, publikasi tentang gen ketahanan penyakit bulai pada tanaman jagung menggunakan penanda molekuler masih belum banyak dilakukan. Informasi tentang gen ketahanan penyakit bulai pada tanaman penting dalam program pemuliaan tanaman.

\section{UCAPAN TERIMA KASIH}

Terima kasih disampaikan kepada Saija dan Romli dari Pusat Inovasi dan Agro Teknologi, UGM atas bantuannya dalam budi daya jagung. Penelitian ini didanai oleh Hibah Insinas 2015, Kementrian Riset, Teknologi, dan Pendidikan Tinggi Republik Indonesia (Nomor: 147 /M/Kp/IV/2015).

\section{DAFTAR PUSTAKA}

Antonio T, Do Amaral J, Erica C, De Olivera, Leandro SAG, Carlos AS, Liliam SC,
Thiago R, Da Concencao S, Cassio V, Keila S,Da Silva. 2011. Assesment of genetic diversity among maize accessions using inter simple sequence repeat markers. Afr J Biotech. 10(69):15462-15469.

Azrai M. 2003. Identifikasi lokus karakter kuantitatif ketahanan penyakit bulai pada jagung menggunakan marka RFLP. Bioteknologi Pertanian. 8(1):8-14.

Azrai M, Hajrial A, Jajah K, Memen S, Jan RH. 2006. Analisis genetik ketahananjagung terhadap bulai. J Pen Pert Tan Pangan. 25(2):71-77.

Blair MW, McCouch SR, Panaud O. 1999. Inter simple sequence repeat (ISSR) amplification for analysis of microsatellite motif frequency and fingerprinting in rice (Oryza sativa L.). Theoretical Appli Gen. 98:780-792. DOI: https://doi.org/10.1007/ s001220051135.

Hartatik S. 2007. Pewarisan sifat ketahanan tanaman jagung (Zea mays L.) terhadap penyakit bulai. Agroteksos. 17(2):99-103.

Idris AE, Nada BH, Samia OY, Ali IA, Haitham KA, El-Amin. 2012. Maize (Zea mays L.) genotypes diversity study by utilization of inters-simple sequence repeat (ISSR) markers. Aus J Basic App Sci. 6(10):42-47.

Muis A, Nurnia N, Marcia BP. 2015. Skrining ketahanan $\mathrm{S}_{1}$ Jagung terhadap penyakit bulai dan pembentukan Galur $\mathrm{S}_{2}$ tahan penyakit bulai. Bul. Plasma Nutfah. 21(1):17-24. DOI: https://doi. org/10.21082/blpn.v21n1.2015.p17-24.

Mustofa Z, I Made B, Gamar BNS. 2013. Variasi genetik jagung (Zea mays L.) berdasarkan karakter fenotipik tongkol jagung yang dibudidaya di Desa Jono Oge. EJIP BIOL. 2(3):33-41.

Pabendon MB, Azrai, Kasim M, Wijaya MJ. 2007. Prospek penggunaan markah molekuler dalam program pemuliaan jagung. Maros (ID): Pusat Penelitian dan Pengembangan Tanaman Pangan, Balitsereal.

Rais SA, Tiur SS, Sri GB, Ida HS, Machmud M. 2002. Evaluasi ketahanan plasma nutfah terhadap penyakit hawar daun bakteri dan blas, dan jagung terhadap penyakit 
bulai. Balai Penelitian Bioteknologi dan Sumberdaya Genetik Pertanian. Hlm 52-62. Rustiani UM, Sinaga MS, Hidayat SH, Wiyono S. 2015. Tiga spesies Peronosclerospora penyebab penyakit bulai jagung di Inonesia. Berita Biologi. 14(1):29-37.

Sokal, Sneath. 1963. Principles of Numerical Taxonomy. San Francisco (US): WH Freeman.

Reddy MP, Sarla N, Siddiq EA. 2002. Inter simple sequence repeat (ISSR) polymorphism and its application in plant breeding.Euphytica.128:9-17.DOI:https:// doi.org/10.1023/A:1020691618797.

Valdemar PC, Paulo MR, Claudete FR, Josue MF, Rosangela MPM. 2002. Assesment of genetic diversity in maize (Zea mays L.) landraces using inter simple sequence repeat (ISSSR) markes. Crop Breed App Biotech. 2(4):557-568. DOI: https://doi. org/10.12702/1984-7033.v02n04a09. 